\title{
社会資本再配分による地域格差 縮小政策について
}

目良浩一*

は じ め に

世界の中に経済的に発展した国と発展の度合いが進んでいない国があるよらに，同一国家の 内部に执いても発展の程度に地域的な差があるのが普通である。この地域間格差は, Williamson が指摘したように経験的法則があり, 国家の経済発展の初期においては比較的小さいが, 経済 発展と共に拡大し, 経済発展がある水準に達するとそれ以後は減退の方向へ向からことが知ら れている1)。

しかしながら，地域間格差は多くの国に拉いて政治的社会的問題として捉兄られ，様々な対 策が実施されているのが実情である。わが国で昭和 37 年に制定された新産業都市建設促進法 は地域格差の解消を主目的とし，その目的を達成するために低開発地域に産業を育成すること を狙ったものである。ほら゙同じ時期に米国ではアパラチア地域の開発のために連邦政府が大規 模な道路建設をすることが決定された ${ }^{2)}$ 。発展途上国に扣いても事情は同様で，ブラジルや大 韓民国では特に工業開発の地方分散によって低開発地域の発展を促進することが主要な政策手 段となっている。

このよらな格差縮小政策は先に述べた経験的法則を多少とも修正しようとするものである。 もっとも, このような地域政策無しの自然的発展が最も経済効率の高い発展過程であるといら 根拠は無いが，このような政策は何らかの意味で個人又は私企業の自発的意志決定に抵抗する ものであるから, 経済効率を損ら可能性はあると考えられる。事実, 地域間所得格差の縮小政 策が経済効率を損ら場合があることは，理論的にも経験的にもすでに示されている3)。

* 筑波大学社会工学系

1) Williamson, J.G. "Regional Inequality and the Process of National Development: A Description of the Patterns," Economic Development and Cuttural Change, 13 (July 1965), part 2.

2) 目良浩一个世界の大規模地域開発の現段階とその意義と特徴：米国」スチール・デザイン No. 118, 昭和 48 年 3 月, $27-28$ 頁.

3) 特に下記の文献参照 : (1) Koichi Mera, Income Distribution and Regional Development (Tokyo: University of Tokyo Press, 1975), chaps V and VI, (2) Roger D. Norton "A Linear Programming Study of Regional Investment Allocations." (Ph. D. thesis, Johns Hopkins University, 1971), (3) Bertrand M. Renaud, "Conflicts between National Growth and Regional Income Equality in a Rapidly Growing Economy: The Case of Korea, "Economic Development and Cultural Change Vol. 21, No. 3 (April 1973), pp. 429-445. 
この論文では, 地域間所得格差の縮小を社会資本の再配分によって行なら場合について考察 し, その経済効率とのトレードオフ関係の経済的意味, 分析方法について検討し, 政策決定に 関しての知識を増大させることを目的としている。

社会資本の再配分を政策手段として考える理由は，それが行政上の公正さを保らながらも特 定地域の開発に寄与できる手段であり，多くの国に拈ける地域格差縮小政策の主要な手段とし て用いられているからである。

\section{地域格差と経済理論}

まずこの問題に取組むに当って指摘したいことは，新古典派の経済理論が地域格差の説明に 非常に非力であることである。すなわち,この派の理論によると, 生産は労働と資本によって もたらされ，報酬の格差によってそれらの生産要素は企業間に配分され，企業は収益性によっ て立地を決定する。従ってこのよらな自由競争を通じて経済は地域間にも通用する一般均衡の 状態に到達し, その状態に执いては同一生産要素は同一地点に执いて同一の価格を持つ4)。こ れを地域間所得格差について解积すれば，労働貨金は地域間で均一となり，資本に対する収益 率も均一となるので, 一人当りの所得は人口の中に占める労働者の数 (労働参加率) と人口当 りの資本の量によって決定されることになる。

しかし実際の所得格差は上記の要因だけによるものであるとは到底考兄られない。経験的な 観点加らいえば, 地域格差の比較的小さい先進国に拈いても, 一人当り所得の地域格差は最高 と最低の比で示すと 2 程度であり, 発展途上国の場合には 5 またはそれ以上に達する場合が ある。

このような地域格差に対して, 労働参加率の地域間格差は通常地域格差の説明にはならない。 一般に農業人口に括ける労働参加率は高いが，農業人口の比率の大きい地域の所得水準は低い。 すなわち, 労働参加率の差は極度の地域間労働力所得の格差を多少緩和する作用をもっている に過ぎない。

一方資産所得については, 確かに高所得地域に扣いて資産所得水準が高く, 労働力所得によ る地域間所得格差を更に拡大していることは事実である。しかしながら，日本の例で澬産所 得は全所得の $10 \%$ 程度であり，他の先進国に拈いてもその比率はそれ程大きくない。従がっ て Borts が示しているように, 資産所得格差が所得格差の大きな要因であるとは一般に考光

4) 特に下記文献を参照：(1) K.J. Arrow and G. Debreu, “Existence of an Equilibrium for a Competitive Economy, "Econometrica Vol. 22 (July 1954), pp. 265-290, (2) Walter Isard and David J. Ostroff, "Existence of a Compelitine Interregional Equilibrium," Papers and proceedings of the Reginal Science Association, Vol. 4, 1958, pp. 49-76, (3) Koichi Mera, "A Multiregion Multisector Model of Equilibrium Growth," The Papers of the Regional Science Association Vol. 21 (1968), pp. 53-75. 
られないらっ。

したがって, 地域間所得格差の主要因を労働力所得および企業家所得の格差に求めざるを得 ない。事実，どの国の統計に扣いても労働力所得に大きな地域格差があることが知られてい る6)。この格差は労働力の不完全移動性から来る不均衡な配分と労働力の質の差によるもので あると考えることができる。

不完全移動性の経済的説明は移動に要する費用である。地域間移動には費用がかつるので, その費用を十分に消却できるような賃金格差がなければ移動は経済的に利益とならない。この ように地域間移動を一種の投資と考えて, 人口の地域間移動を説明する仮説が提案され, 実証 的にも妥当であることが示されている。しかし，この妥当性は実際に地域間移動を行なったも のについてのみ有効であり，すべての人がこの経済計算によって移動をするかしないかを決定 するわけではない。すなわち，地域間移動の費用は比較的小さく，多少の賃金格差があれば地 域間移動が経済的に合理的であるといらことになるからである。従がって地域間移動の費用だ けでは地域間貨金格差の大部分を説明できないだけでなく，その説明として大きな助けとはな らない。すなわち, 不完全移動性は経済性ばかりでなく, 社会的文化的要因にも起因する。乙 かし，長期的には経済性に基ずいた地域間移動が続行し徐々に労働力配分は均衡に近ずく筈で ある。ところが，実際には均衡化現象はそれ程明瞭には観察されない。

占金格差，更に広義には労働所得格差が地域間に持続されるのは，先に指摘した労働力の質 が地域間で異なるためであると考えられる。しかし，この説も労働所得の地域格差の一部を説 明するに過ぎないことが知られている7゙すなおち，一つは産業間格差であり，他は都市規模 間格差である。後者は地域間所得格差を考えるために非常に重要である。

今までのクロスセクションによる生産関数の分析によると, 生産関数には集積の経済性があ ることが知られている8)。この集積の経済性は第一次産業においては皆無かむしろ不経済性が

5) 日本において個人の財産所得の国民所得に占める比は 1951 年度の $4.1 \%$ から漸次増加して 1973 年度 には $12.8 \%$ 亿達している。これ個人業主所得の此率の減少に伴なっているもので, 雇用者所得に対 しては 1951 年度の約 9\% から，1973 年度の $21 \%$ まで漸次增している。経済企画庁編，国民所得統 計年報・昭和 50 年版, 参照。米国については下記の推計がある。George H. Borts, “The Estimation of Produced Income by State and Region," Studies in Income and Wealth, Vol. 27 (Princeton, N.J.: Princeton University Press, 1964), pp. 317-381.

6) 日本の柰民所得の統計によると，総県民所得に占める雇用者所得，個人業主所得㧍よび個人の財産所 得の此率が都道府県間でほぼ定であるので, 所得格差と同程度の格差が学働力所得又は雇用者所得 にあると考えられる。経済企画庁経済研究所国民所得部監修, 紧民所得統計 (昭和 30-46 年度)，(東 京：至誠堂, 昭和 49 年) 参照。

7) Victor R. Fuchs, Differentials in Hourly Earnings by Region and City Size, 1959, National Burean of Economic Research Occasional Paper No. 101 (New York: Columbia University Press, 1967).

8) 下記文献参照： (1) Koichi Mera, "Regional Production Functions and Social Overhead Capital: An Analysis of the Japanese Case," Regional and Urban Economics, Vol. 3 (May 1973), pp. 157-186. (2) Daniel Shefer, "Localization Economies in SMSA's: A Production Function Analysis," Journal of Regional Science, Vol. 13 (April 1973), pp. 55-64, (3) Lee 
ある傾向があるが，第二次産業には明らかに存在し，第三次産業ではより顕著である。今まで の著者の分析の結果では, この経済性は規模の経済性としてょりも, むしろ密度の経済性とし て捉えた方が良いといら結果が出ている9)。ここで密度の経済性とは，単位面積内の生産要素 のすべてを $\alpha$ 倍に增大すると，生産量は $\alpha$ 倍以上になるといら意味である。この密度の経済 性は主に交通・通信・ユーティリティ等の距離の関数であるインプットの節約と近接性の増大 による知識交換の増大による生産性の向上などによるものと考えられる。特に, 密度の経済性 が生産品が比較的均一である第一次産業になく，生産品が極めて不均一な第三次産業に著しく 見られることは，知識の流動量が密度の経済性の大きな要因となっているであろらことを示唆 している。

このよらな密度の経済性がある場合に生産による収入がどのように分配されるかについては 近代経済学は答えてくれない。確かなことは, 生産要素に対してその限界価值生産性に等しい ものが支払われるといら原則が一般に成立しないことである。

すなわち, 地域間所得格差を理解するに当っては, 新古典派経済理論が一般に想定する前提 のらち下記のものは成立しないといらことを了解する必要がある：

[1] 生産関数が一次の均等性 (homogeneity) をもつ

[2]生産要素に対してはその限界価值生産性に等しいものが支払われる。

\section{社会資本と地域の生産}

地域の生産は更にその地域内の社会資本の量によって影響されることが知られている10)。こ の事実は各産業に直接関連のある社会資本を民間資本とは別個に生産関数の要素として関数を 推計することによって確かめられるし，社会資本と他の生産要素との関連を考えることによっ ても理解できる。

社会資本の量が生産に影響することは, 二重の意味で興味深い。第一には社会資本の限界生 産がぞこに㷌属しているかといら分配の問題であり，第二には政府は社会資本の地域的配分を 変化させることにより地域の生産性を变化させることができるといら事である。

分配の面については, 実は, 規模又は密度の経済性から来る限界価值生産性による所得分配 論に基ずく必要総所得と可配分総所得の差異は，社会資本の提供者である政府が報酬を受けな

Sveikauskas, "The Productivity of Cities, "Quarterly Journal of Economics, Vol. 89 (August 1975), pp. 393-413, (4) Tatsuhiko Kawashima, "Urban Agglomeration Economies in Manufacturing Industries," Papers of the Regional Science Association, Vol. 34 (1975), pp. 157-175.

9) 特に前注 Mera 又は Koichi Mera, Income Distribution and Regional Development (東京：東 京大学出版会, 1975) Chap. IV. 参照。

10) 前注 Mera 参照。 
いといらことによって補填されているのかも知れないのであるが，政府又は公共機関が徴収す る税金又は料金が社会資本の生産への貢献度とどのよらな関係にあるかを知らなければ，真の 社会資本の所得への貢献度は計測できない。

しかしながら，料金，税率等は政府の方針で決定できるものであるから，それらの率の調整 と共に社会資本の量自体を調整することにより，より望ましい地域の生産を導くことができる。 多くの地域間所得格差是正政策が，低開発地域への社会資本の供給を增大することによって達 成しょらとする背後には暗黙のうちに社会資本の果すそのような役割への理解があるわけであ る。

ただし，社会資本の量の増大がぞのような過程で地域の生産の増大を導くかはよく知られて いない。一つの見解は社会資本は単に生産要素の一つとして生産関数内で作用するといら考え で，この考えによると社会資本の投入は他の生産要素の量を変動させないので，社会資本の增 大による生産の増加率は生産関数に打ける社会資本の生産弾性值によって決定されることにな る。この值は 0.1 を中とし, 大きくても 0.2 程度であるから, 地域の生産を $10 \%$ 增大する ためには $50 \%$ から 100\% の社会資本の增加が必要であることになる11)すすおわち, 多大な量 の社会資本の投入が何らかの効果を挙げるために必要となって来る。

しかし，この考光は長期的には必ずしも正しくない。社会資本の投入によって民間資本及び 労働力の生産性が向上すればそれぞれの生産要素の投入を誘導するわけでその面からも地域の 生産は増大して来る筈である。その際には当然, 地域人口の方も増大するわけで, 一人当り所 得とすれば長期的には集積又は密度の経済性による分だけ所得水準が上升することになる。

上記のよらな長期的な観点からすれば，社会資本の投入は他の生産要素である民間資本およ び労㗢力を導入するための手段であると考えられる。そしてその成果は主に密度の経済性の獲 得であるといえる。しかしながら，社会資本の投入が実際にある一定期間内にどれだけの民間 生産要素の吸収力を持つかについてはあまり良く知られていない。現存のデータから得られる ものはある時点に拈壮る地域別の生産要素の賦与状況であり，時系列データを検討することに よってその相互関係を解明することは理論的には可能であるがそれについての満足すべき㭘討 はまだなされていない。

しかしながらこのよらな長期的な生産要素配分の調整が完了した時の社会資本投入の所得効 果を予測することはできる。密度の経済性のない第一次産業を除くと第二次産業扣よび第三次 産業の生産関数の均等性の次元 (Order of Homogeneity) をそれぞれ 1.05 と 1.10 とすれば, それぞれの生産要素の密度が 2 倍になった時の生産性の上昇はそれぞれ $3.5 \%$ と7\% である12)。

11) 社会資本の生産弾性值は 0.06 から 0.22 の範囲にあると推定されている。前注 Mera 参照。

12) 交通・通信社会資本の扱いによって 1.25 という推計もあるが, 第二次産業における均等性の次元は 1.03 程度，第三次産業においては 1.1 程度であると推計されている。前注 Mera 参照。 
従がって，社会資本の投入によって産業の構成比率が変化しないとすると，社会資本の投入が 持つ所得効果は短期的效果の方が長期的効果よりもむしろ大きいといら可能性もある。しかし， いずれにせよ，上記のように考えると社会資本投入による所得効果は一般に極めて微弱である と言えよう。

上記の分析では，社会資本投入による産業構成比の变化は無いと仮定していたが，この仮定 は現実的でなく，少なくとも社会資本投入に際しての政府の意図としてはその地域の産業構造 の変革がある。しかも産業間労働所得の格差は比較的大きいので社会資本投入が産業構造を有 利な方向に導いて行くことが出来れば，社会資本再配分の効果は前述よりも大きくなる。

このような構造変化をも含めて社会資本量と就業者一人当りの所得との関係式を求めて得ら れたものが次式である：

$$
(y / e)=0.27174+0.0009863 g-0.000000597 g^{2}
$$

ただし $y / e$ は就業者当りの生産所得で単位は百万円, $g$ は一平方籸米当りの社会資本で単位 は百万円

で, 1963 年のデータについて推計された ${ }^{13)}$ 。この式をもって社会資本密度の下限に近い県の 社会資本を倍增すると就業者当りの生産は約 $9 \%$ 增加し, 社会資本密度が中庸の県の社会資本 密度を倍增すると約 $16 \%$ 增加することが知られる。

\section{地域格差縮小政策と経済効率}

上記のように社会資本の再配分は地域間所得格差を縮小寸る手段として有効であるといらこ とは事実であると考えられる。しかしながら，国家的見地からの経済効率から考学ると望まし くない手段である。何故なら, 上記の議論を極度まで推し進めるならば, 最も効率的な資源の 地域的配分は, 農業生産地に拈いてはその他の産業を全く排除して農業就業者当りの土地面積 を拡大し，第二次扣よび第三次産業はすべて一地域に集中させて集積の経済を最大限に活用す ることになる。

このような状態に抽いては地域間所得格差は産業間格差と集積の差による格差によって極め て大きくなると考えられる。自由競争的要因に大きく支配された実際の経済活動の分布はこの ような極端な形ではないが，それに極めて近いものであると考えられる。

このような状態から社会資本の再配分によって地域間所得格差を解消することを想定すると， まず第一に各地域の社会資本密度を均等化し, それに従って民間生産要素が汪注均等に再配分 されることを狙らことになる。この際には極度に経済効率が高い高密度都市地域が解消させら

13) Koichi Mera, "Trade-off between Aggregate Efficiency and Interregional Equity: The Case of Japan, “Regional and Urban Economics Vol. 3 (August 1973), pp. 273-299 又は Income Distribution and Regional Development (東京: 東京大学出版会, 1975) Chap. VI, p. 175 参照。 
れるために国全体の経済効率の低下が起る。1963 年の日本全体を都道府県別に分け地域間所得 水準を均一化した場合の試算では，そのよらな社会資本再配分による経済効率の低下は GNP で計って約 $12 \%$ と推定された ${ }^{14)}$ 。

上述のように集積の利益がある以上，地域間所得格差が発生するのは経済的必然である。そ れに対抗して地域間所得均等化政策を展開した場合には国家的見地からの経済効率の低下は止 むを得ない代償となる。

しかし，上記の議論は集積の経済法則が不変であるとした場合のものである。一般に先進国 間では先進であるほどに地域間所得格差が小さいといら事実は, この集積の経済性が経済発展 と共に弱まって行くことを示していると考兄られる。交通・通信技術や施設の発達による空間 的抵抗の退化や教育・訓練の普及などがその主な要因であると考えられる。事実日本の都市で もドーナッ現象が起り大都市は外延的に拡大して行く方向にあり, 地域間の所得格差も縮小し, 地方の人口も定着化の傾向を示している。

このよらな変化には, 一般交通・通信網の発達の他に, 国鉄新幹線, 高速道路, 旅客航空, 電話の自動ダイアル化，テレビジョンなどの普及発展などが大きな役割を果していると考えら れる。従がって低開発地域の開発のためには, 単にその地域内の社会資本を充実させる他に, その地域を先進地域と密接に連結するといら社会資本の投入の方法もある。しかも, この方法 は比較的に効率の良い方法であるとの結墖も出ている15)。

今後, 社会資本の再配分によって地域間所得格差を縮小する政策を採るに当っては, このよ らな代替案も考えなければならない。更に, 近年特に反対運動が高まって来ている大形交通幹 線建設の破寨はそのような格差保全効果を持つことも十分に考慮して扣く必要がある。

\section{結 論}

地域の経済では単純な新古典派的解釈では理解できない事項が数多くある。例えば所得の分 配理論も不十分であるし，集積又は密度の経済性があることも容認しなくてはならない。この ような理論的困乱の中で地域間の一般均衡理論を講築することには多くの困難がある。

一方, 経験的にみると地域間所得格差解消手段として使用されている社会資本の再配分政策 は一応の効果があると推定される。しかしその手段で特定の地域の所得水準を上げるためには かなり大量の社会資本の投入が必要であると推定される。一方そのような所得水準の均等化は 自然的経済法則に反するものであるために，国家的経済効率の観点からは損失が大きい。

\footnotetext{
14) 前注参照。

15) 経済企画庁経済研究所「全国地計量モデルの研究」研究シリーズ第 18 号, 昭和 42 年 10 月。特に第 5 章参照。
} 
従がって, 今後の方向としては集積の経済性を減退させるような, 又はそれを遠くへ拡散す るような社会資本の充実によって地域格差を縮小して行く方針について十分に検討する必要が ある。 